\title{
Research Paper \\ The Effect of Acceptance and Commitment Based Therapy on Psychological Distress and Negative Automatic Thoughts in Mothers of Children with Cerebral Palsy
}

\author{
Azadeh Tork $^{1}$, Ilnaz Sajjadian ${ }^{* 2}$ \\ 1. M.A. in Clinical Psychology, Isfahan (Khorasgan) Branch, Islamic Azad University, Esfahan, Iran \\ 2. Assistant Professor, Department of Psychology, Isfahan (Khorasgan) Branch, Islamic Azad University, Esfahan, Iran
}

Citation: Tork A, Sajjadian I. The effect of acceptance and commitment based therapy on psychological distress and negative automatic thoughts in mothers of children with cerebral palsy. Quarterly Journal of Child Mental Health. 2020; 6(4): 156-167.

http://dx.doi.org/10.29252/jcmh.6.4.15

\section{A R T I C L E I N F O}

\begin{tabular}{l}
\hline Keywords: \\
Psychological distress, \\
negative automatic \\
thoughts, \\
acceptance and \\
commitment therapy
\end{tabular}

Received: 5 May 2018 Accepted: 26 Dec 2018 Available: 4 Mar 2020

\begin{abstract}
A B S T R A C T
Background and Purpose: Cerebral palsy is one of the most common causes of motor disability in children which causes many psychological problems in them. Because these children need the constant care and support of their parents, they create many stresses and problems for all family members, especially the mother. The purpose of this study was to determine the effectiveness of acceptance and commitment based therapy on psychological distress and negative automatic thoughts in mothers of children with cerebral palsy.

Method: This was a quasi-experimental study with pretest-posttest and follow-up with control group. The statistical population consisted of all mothers of children with cerebral palsy in Dorud city in the academic year of 2017. Sample size in this study consisted of 30 mothers from the mentioned papulation who were selected by convenient sampling method and were randomly divided into experimental and control groups. Data collection tools included Brief Symptom Inventory (Derogatis, 2000) and Automatic Thoughts Questionnaire (Hollon \& Kendall, 1980). Acceptance and commitment based therapy was given to the experimental group for 8 sessions of 90 minutes. Data were analyzed using repeated measures analysis of variance.

Results: The results showed that acceptance and commitment based therapy had a significant effect on decreasing the dimensions of psychological distress (somatization, depression, and anxiety) and negative automatic thoughts (amount of thoughts and beliefs about thoughts) $(\mathrm{p}<0.05)$. The effect size for the dimensions of psychological distress were $0.66,0.56$, and 0.71 , respectively, and for the dimensions of negative automatic thoughts were 0.58 and 0.73 , respectively

Conclusion: The results of this study emphasize the usefulness of acceptance and commitment therapy in reducing psychological distress and negative thoughts in mothers of children with cerebral palsy, so this training can be used as an effective method of reducing Psychological problems and improve the mental health of mothers with children with cerebral palsy.
\end{abstract}

\footnotetext{
* Corresponding author: Ilnaz Sajjadian, Assistant Professor, Department of Psychology, Isfahan (Khorasgan) Branch, Islamic Azad University, Esfahan, Iran.

E-mail addresses: I.sajjadian@gmail.com
} 


\section{تأثير درمان مبتنى بر يذيرش و تعهد بر درماند مى روانشناختى و افكارخودآيند منفى مادران داراى كودك مبتلا به فلج مغزى}

\section{r** آزاده تر كى'، ايلناز سجاديان}

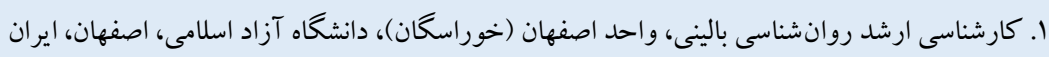

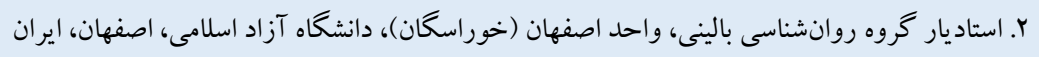

\begin{tabular}{|c|c|}
\hline جكيده & مشخصات مقاله \\
\hline زمينه و هدف: فلج مغزى از شايع ترين علل ناتوانى حركتى در كود كان به شمار مى رود كه باعث مشكلات روانشناختى فراوان در آنها & 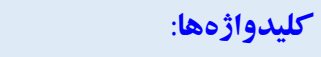 \\
\hline مى شود. از آن جايى كه اين كود كان به مراقبتها و حمايتهاى مستمر والدين نياز دارند، تنيدگى ها و مشكلات زيادى را براى تمامى اعضاى & 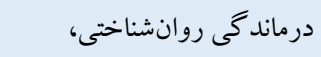 \\
\hline خانو اده بهخصوص مادر ايجاد مى كنند. بدين ترتيب اين يُزوهش با هدف تعيين اثربخشى درمان مبتنى بر بذئيرش و تعهل بر درماندگى روان & افكار خود آيند منفى، \\
\hline شناختى و افكار خودآيند منفى مادران داراى كودك مبتلا به فلج مغزى انجام كرفت. & درمان مبتى بر يذ يرش و تعهد \\
\hline روش: اين بثوهش نيمه آزمايشى از نوع بيش آزمون-بِ آزمون با گروه گو اه و ييخيرى يكك ماهه بود. جامعه آمارى شامل تمامى مادران & \\
\hline داراى كود كك فلج مغزى شهرستان دورود در باييز هوسا بود كه از بين آنها با استفاده از روش نمونه كيرى در دسترس تعداد ·ب نفر انتخاب & \\
\hline و به طور تصادفى در دو گروه آزمايش و گگواه جايدهى شدند. ابزارهاى گردآورى دادهها شامل يرسشنامه نشانهشاسى & \\
\hline 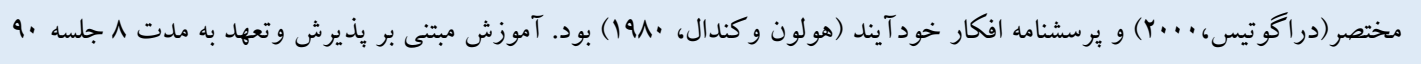 & \\
\hline دقيقهاى به گروه آزمايش آموزش داده شد. تحليل دادهها با استفاده از تحليل واريانس اندازهگيرى مكرر انجام گرفت. & \\
\hline يافته ها: نتايج نشان داد كه درمان مبتنى بر يذيرش و تعهد بر كاهش ابعاد درماندگى روانشناختى (جسمانى سازى، افسردگى، و اضطراب) & \\
\hline و افكار خود آيند منفى (ميزان افكار و باور به افكار)، تأثير معنىدارى دارد (ه./·p). ميزان اندازه اثر براى ابعاد درماندگى روانشناختى به & \\
\hline 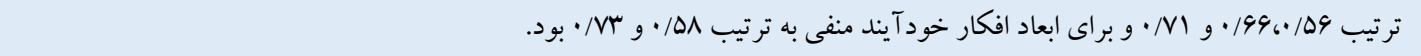 & \\
\hline نتيجه كيرى: نتايج اين يزوهش سودمندى درمان مبتنى بر يذيرش و تعهد را در كاهش درماند كى روانشناختى و افكار خودآيند منفى & 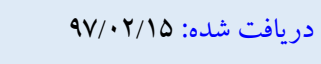 \\
\hline مادران داراى كودكى مبتلا به فلج مغزى مورد تاكيد قرار مىدهد، در نتيجه مىتوان اين آموزش را به عنوان يك روش مؤثر در كاهش & 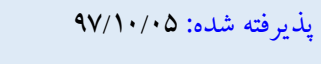 \\
\hline مشكلات روانشناختى و بهبود سلامت روانى مادران داراى كودكك مبتلا به فلج مغزى به كار برد. & 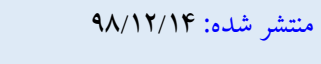 \\
\hline
\end{tabular}

* نويسنده مسئول: ايلناز سجاديان، استاديار گروه روانشناسى بالينى، واحد اصفهان (خوراسكان)، دانشكاه آزاد اسلامى، اصفهان، ايران. رايانامه: I.sajjadian@gmail.com

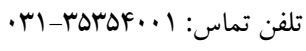


اين مســئله بـه نوبـه خود مي تواند از كمكك به بازتوانى افراد داراى فلج

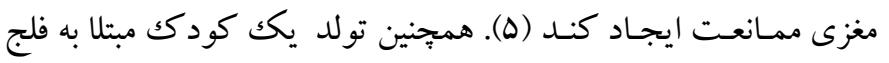

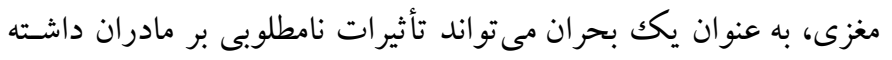

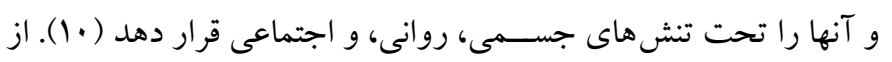

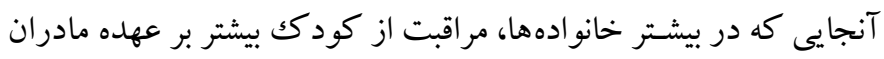

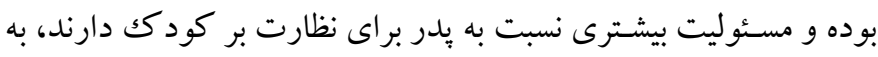

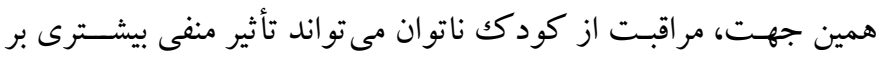

وضعيت روانشناختى مادران داشته باشد (11).

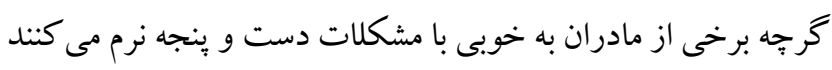

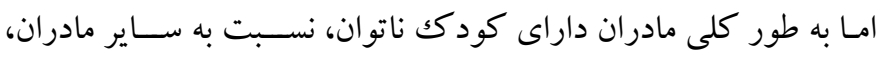

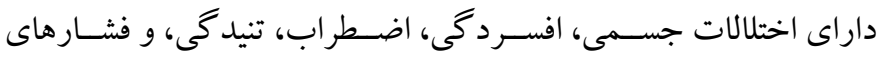

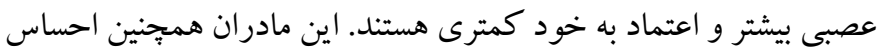

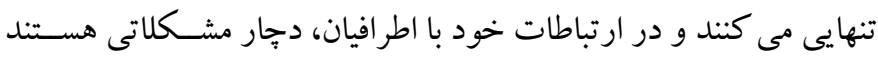
(9)؛ زيرا وجود كود كك بـا اختلـال فلج مغزى در خانو اده، احســاســات

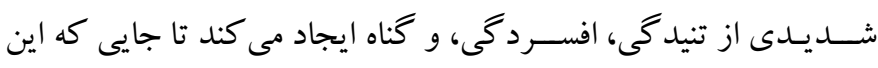

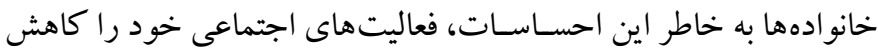

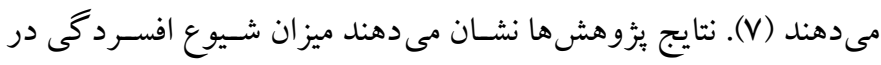

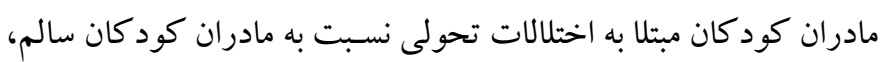

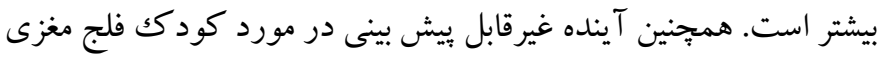

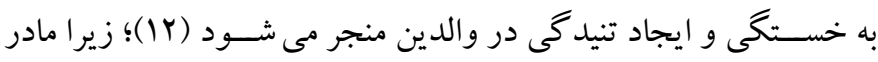
نخستين كسى است كه به طور مستقيم با كودكك ارتباط بر قرار مى كند و احسـاساتى مثل گناه، تقصير، كامنايافتخى، و محروميت ناشى از بهنجار

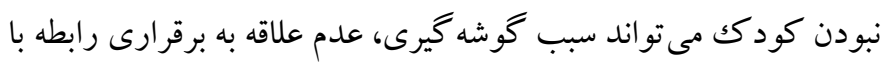

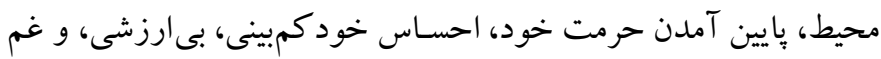

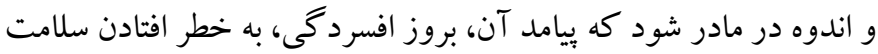

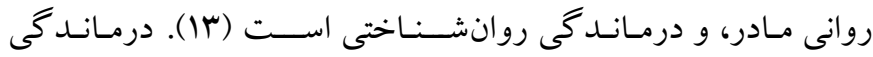
روانشـناختى به صـورت جسـمانى سـازى، افسـردگى، و اضـطر اب بروز

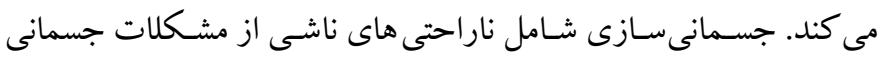

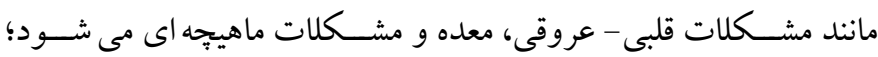

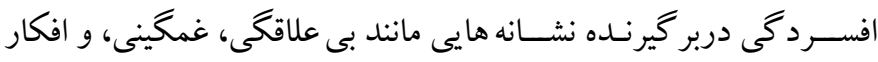
خود كشى اسـت؛ و بالاخره اضـطر اب به احسـاسـات ترس، عصـبانيت،
مقلهم تولد كودك،، عامل گسترش نسل و سبب تغيير ساختار خانو اده است و به

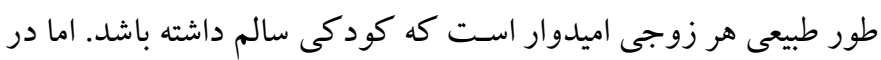

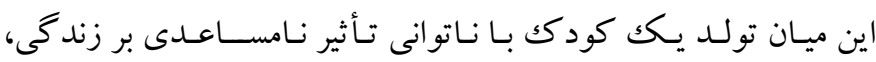
هيجانات، افكار، و رفتار اعضـاى خانواده دارد (1). در ميان ناتوانىهاى كود كان، فلج مغزى ' از شـايع ترين علل به شـمار مى رود كه باعث بروز

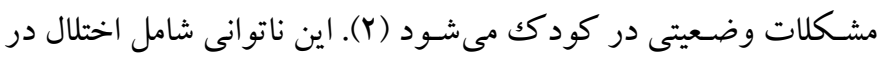
حركت و حالت بدنى ناشى از يكك مغز رشد نايافته و داراى آسيب بودهد

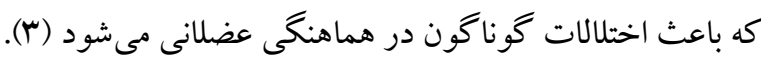

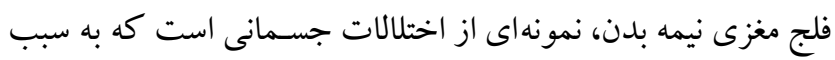

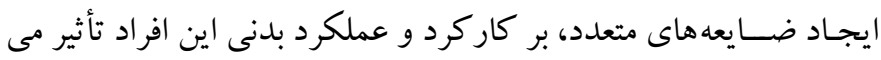

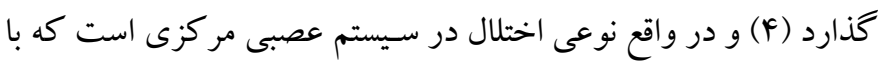

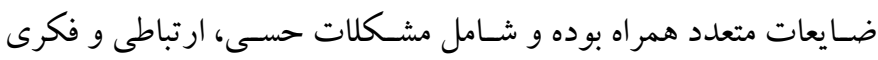

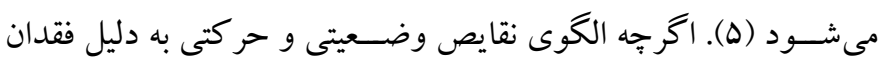

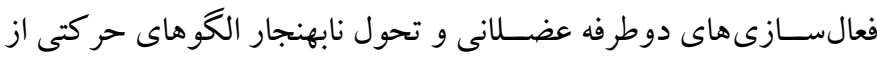
مشـخصـات تعريف شــده فلج مغزى اسـت، اما تعداد زيادى از اختلالات ثانويه ماند نقايص شناختى، حسى، و روانى - اجتماعى نيز با اين تشخيص

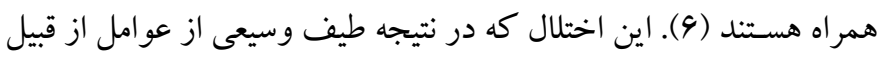

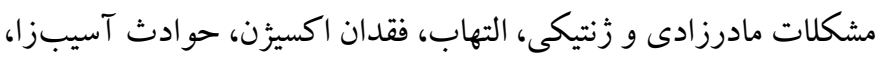

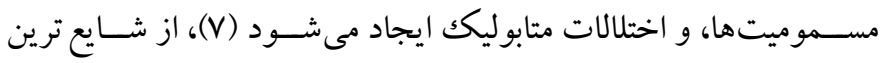

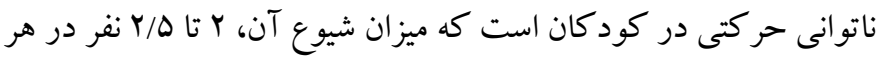

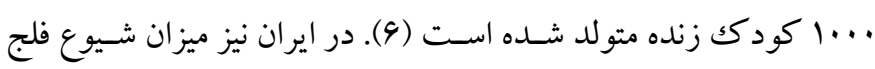

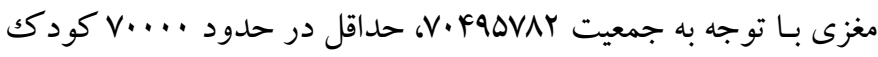
است (A).

كود كـان بـا فلج مغزى، محدوديتهاى مشــخصسى در فعاليتهاى روزانه از قبيل غذا خوردن، لباس يوشيدن، حمام رفتن، و جابجايى دارند

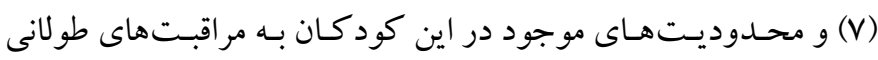

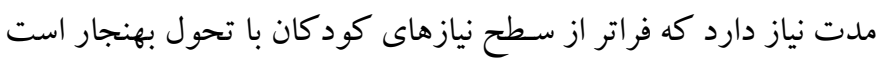
و فشــار زيادى را بر مراقب به طور عمده هم مادران ، وارد مى كند (9).

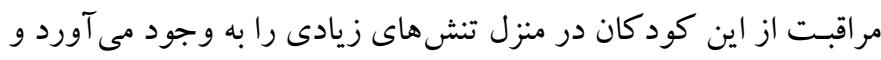

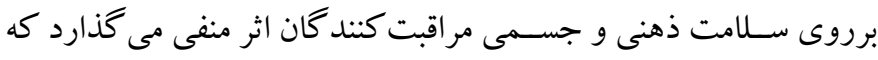


يكى از اين روشهـاى جـالب كه موج ســوم روى آوردهاى شــناختى -

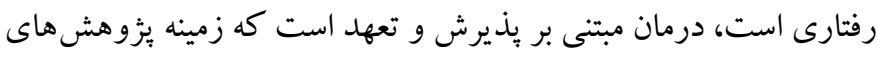

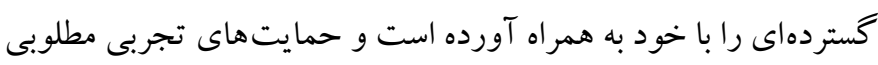

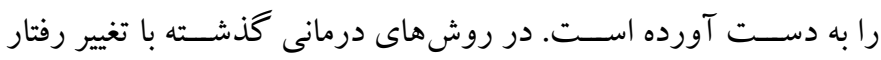

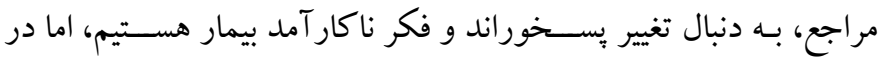

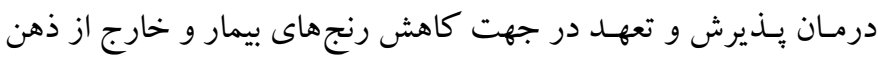

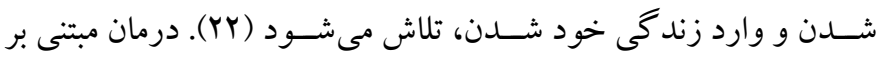

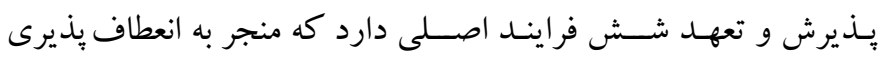

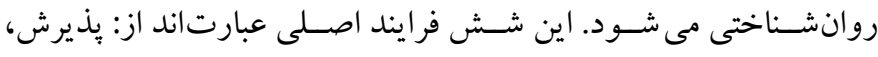

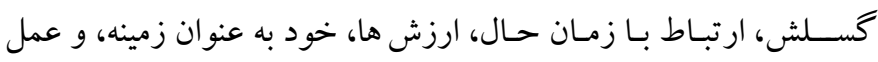

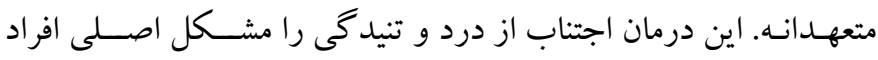

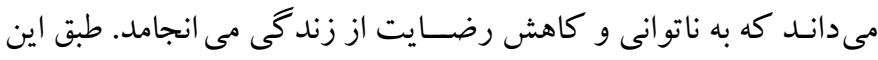

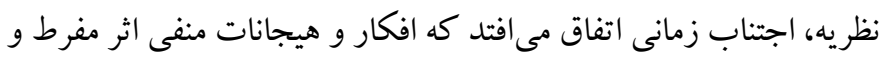

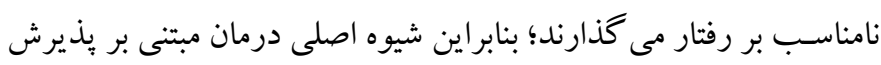

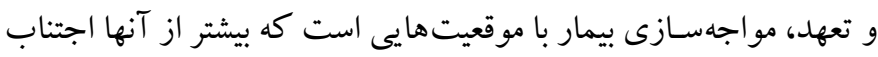

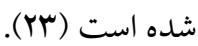

از زمان ظهور و گســترش درمان مبتنى بر بذيرش و تعهد، اسـتقبال

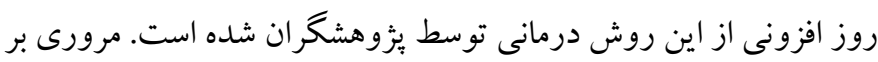

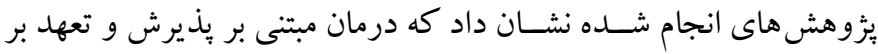

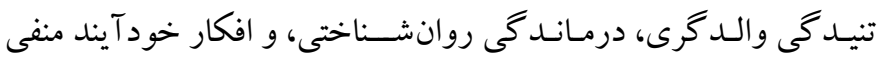

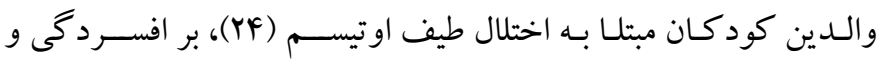

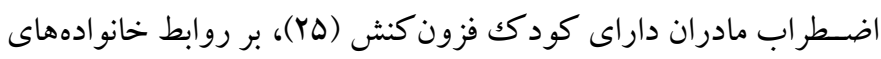

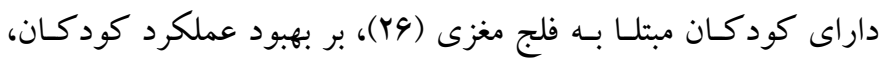

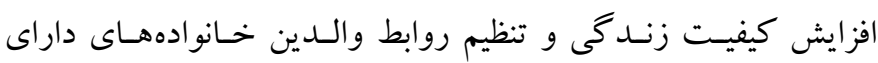

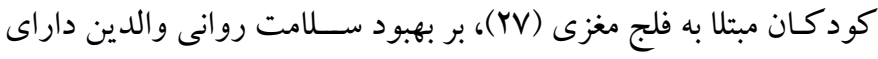

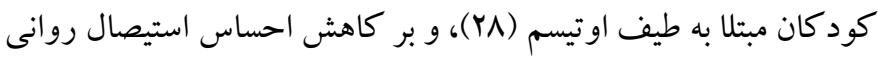

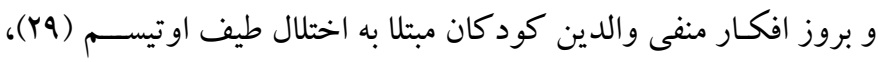

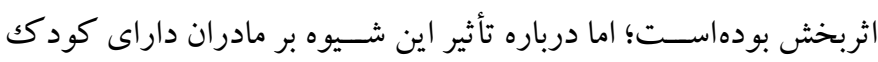

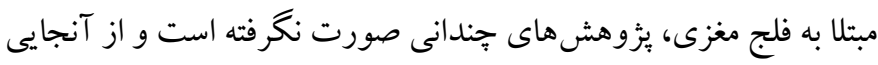
كه فلج مغزى بعد از كم توانى ذهنى و اوتيسمم، سومين تشخيص شايع در

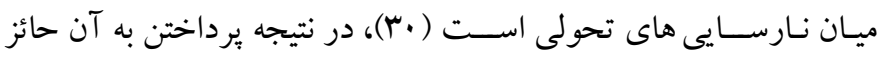

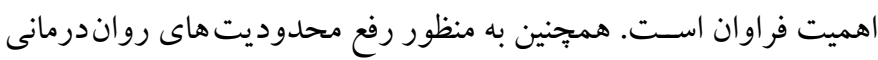

وحشـتـ، و تشــــيش مربوط مى شــود (IF). طبق نظريه اشــايدر (10)

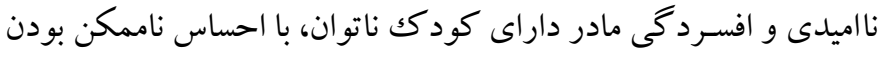

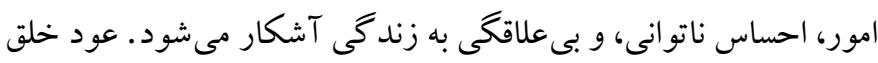

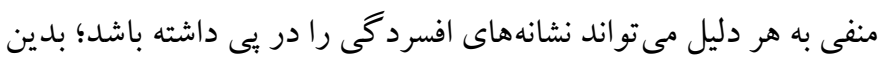

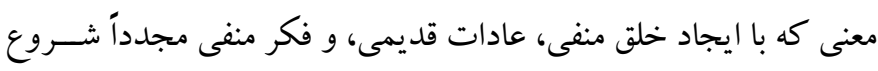

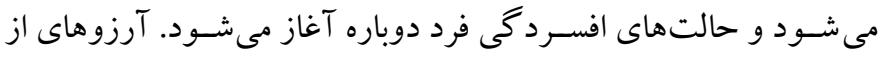

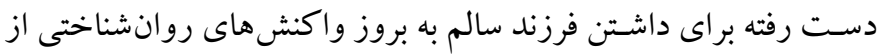

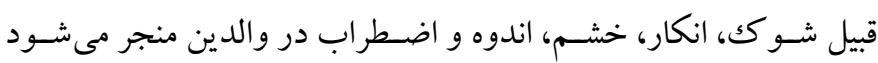

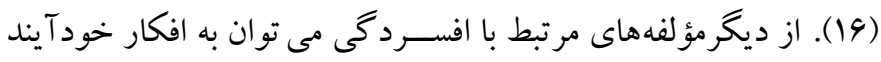

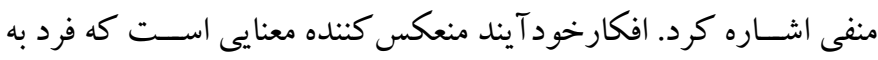
موقعيتى خاص مى دهد و با باسخ هيجانى و رفتارى به آن موقعيت ارتباط

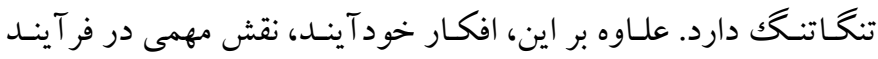
درمانى دارند و به عنوان گذر گاهى ترجيحى براى دستر سـى به سـيستم

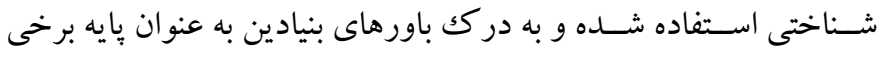

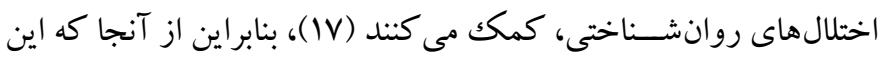
متغير با ارزيابى منفى افراد از خود، جهان، و آينده همراه اسـت مى تواند در بروز رفتارهاى سـازش نايافته نقش داشـته باشـــ (1) ). ئزوهش ها نشان

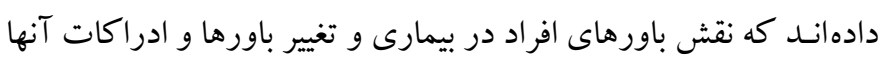

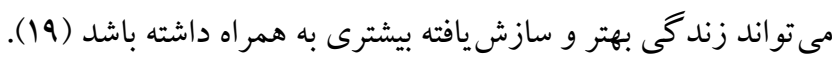

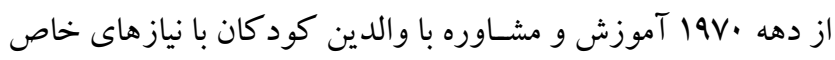
به دليل نقش اسـاسـى آن در بيشــــت هر گونه برنامه مداخلهاى و تأثير

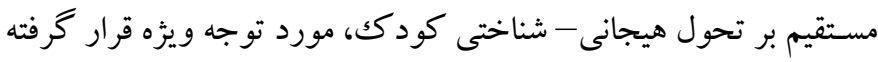
است (·r). از طرفى دريافت درمانهاى مختلف از قبيل دارو، جر احى، و و برنامههاى مكرر تو انبخشى براى والدين علاوه بر فشارهاى مالى، مشكلات

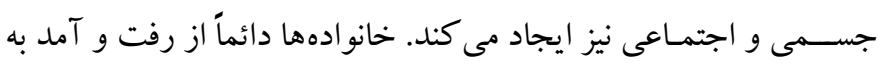

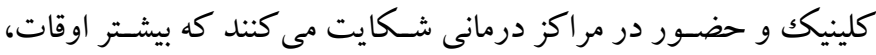
مادران براى انجام اين درمانها اقدام مى كنند و شايد همين عامل به به بروز

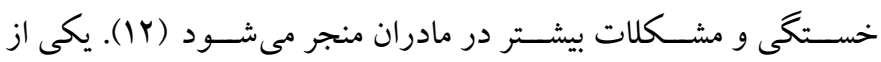

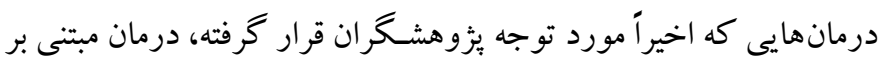

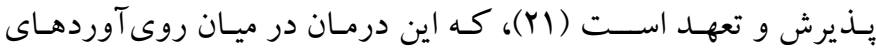
روانشـناختى موج سـوم، از توانايى خوبى در مهار نخرشهـا و ادراكات

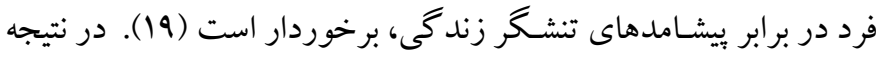


درصــ)؛ و تعداد افر اد داراى مدرك كارشــناسـى ارشــــ و بالاتر، ^نفر

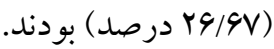

ب)(ابزار

ا. برسشنامه نشانهشناسى مختصر ': اين برسشنامه توسط درو گاتيس (1)

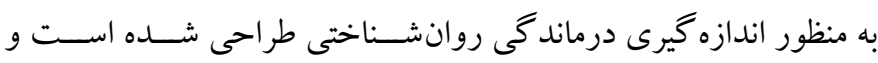

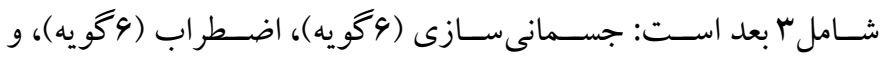

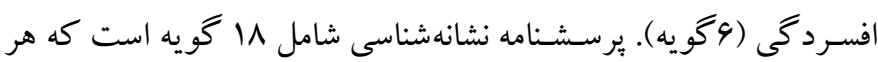

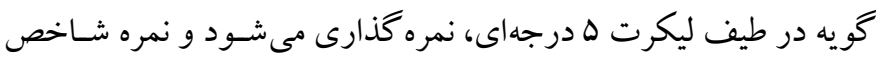

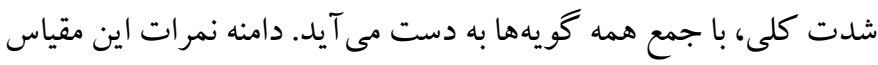

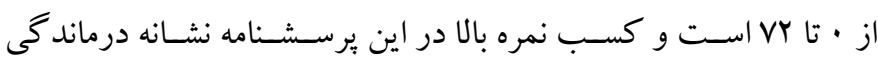

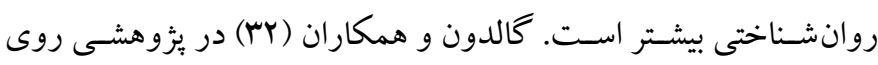
نمونه IVD نفرى از بيماران مبتلا به سرطان سينه، سه عامل جسمانى سازى،

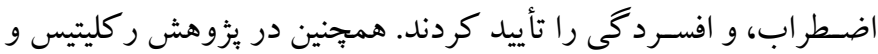

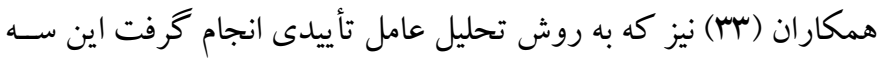

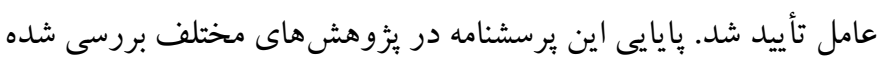

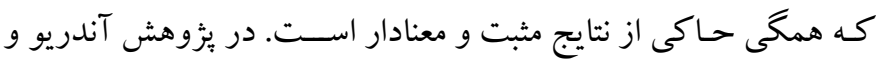

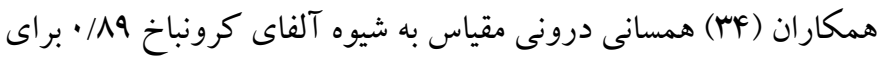

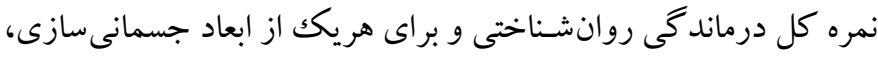

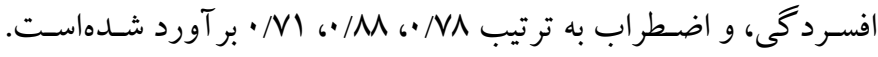

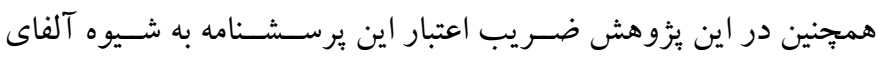

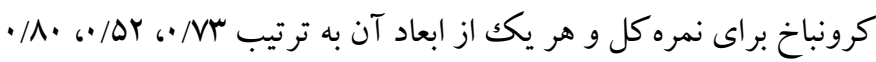

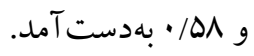

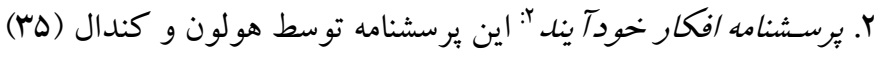

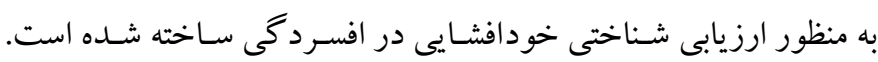

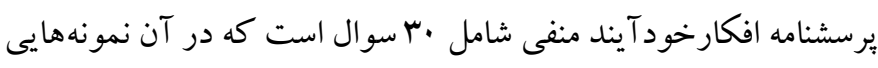

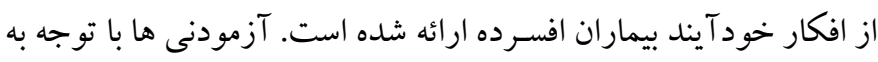

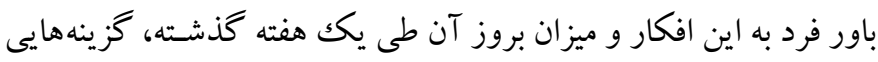

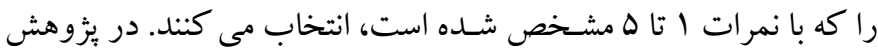

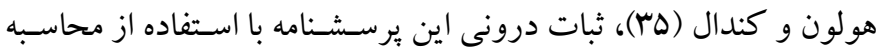

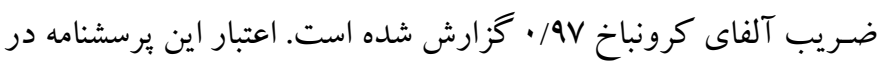

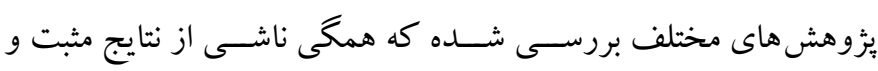

فردى مانند هزينه بالا و ميزان زمان مورد نياز و با در نظر گرفتن مزيتهاى رواندرمانى گروهى مثل يويايى گروهى و تسهيل تخليه هيجانى، نياز به

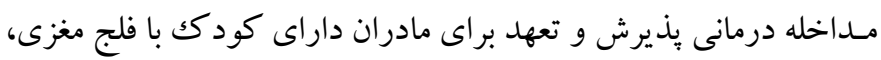
دوجندان مىشـود. بدين ترتيب مطالعه حاضسر با هدف تعيين اثربخشى

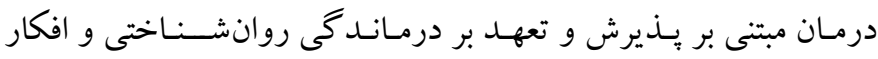

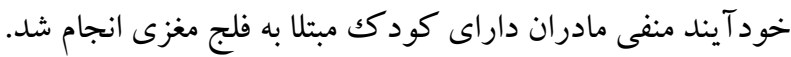

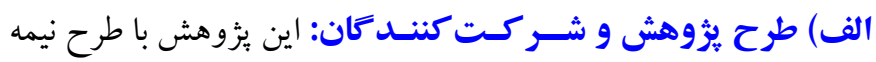

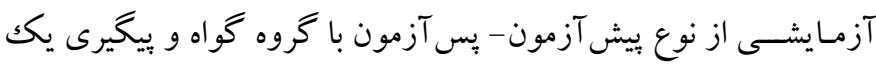

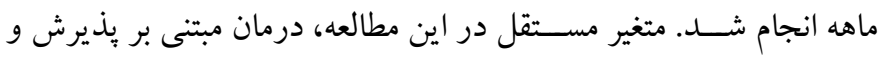

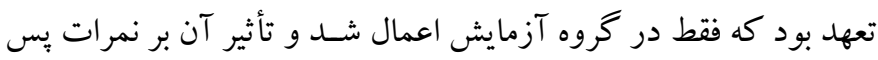

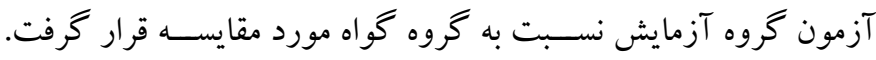
جامعه آمارى يثزوهش حاضــر شــامل تمامى مادران داراى كود كك فلج مغزى مر اجعه كننده به كلينيك تو انبخشى و بهزيستى شهرستان دورود (از شـهرهاى شـرق استان لرستان) در باييز هوها بود. براى انتخاب نمونه در

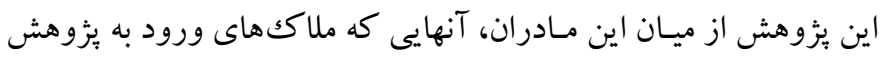

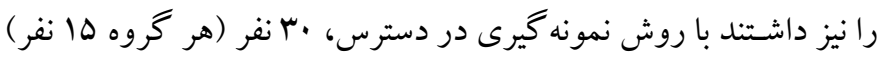

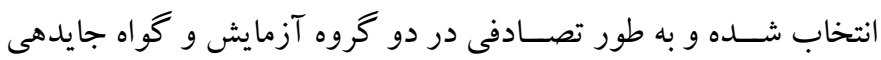

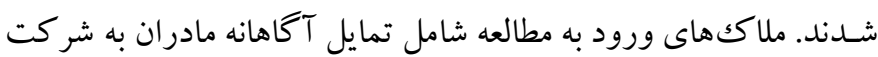

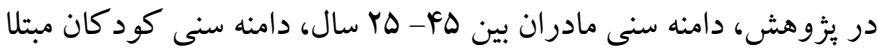

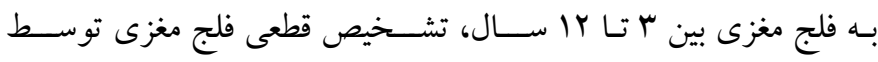
متخصص مغز و اعصاب و يا متخصص اطفال، و حداقل تحصيلات سوم راهنمـيى براى مادران بودند. همجنين غيبت بيش از دو جلســه مادران،

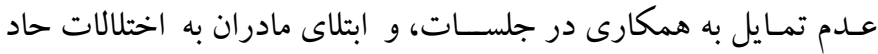

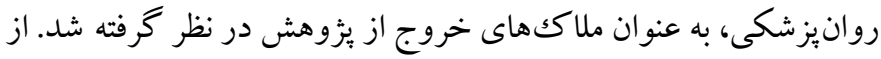

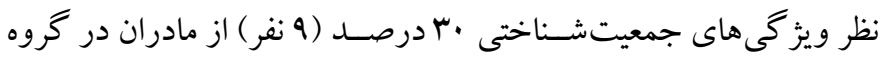

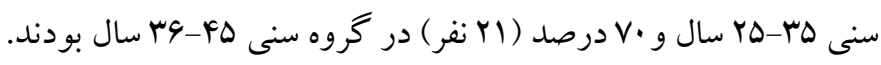

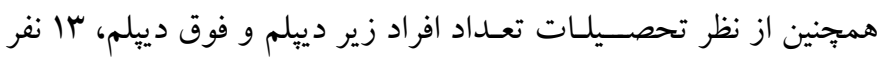

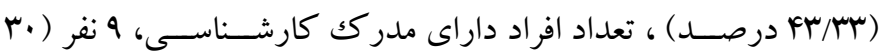


ميز ان افكارخود آيند منفى •9/ • و براى باور به افكارخودآيند منفى Y9/.

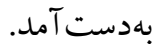

ج) برنـامــه مــداخلهاى: براى آموزش مبتنى بر بذيرش و تعهد در اين

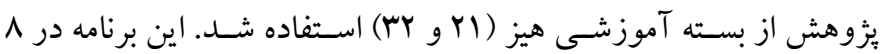

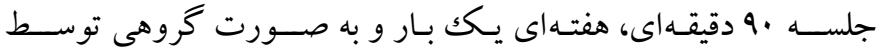
كارشـناسى ارشد روانشناسى بالينى داراى مجوز دوره درمانى يذيرش و و تعهد در مر كز بهزيستى شـهرستان دورود بركزار شــــ خلاصسه جلسات آموزشى در جدول المرائه شده است.
معنى دار اســت. در بثزوهش باباميرى و همكاران (1) اعتبار اين ابزار به

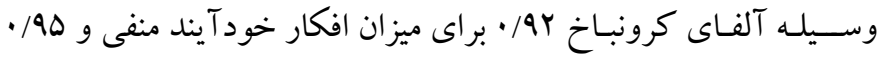

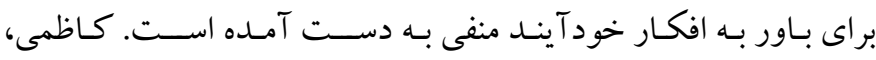

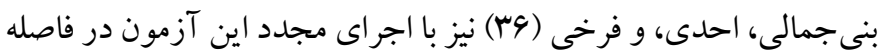

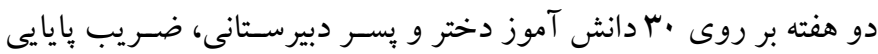

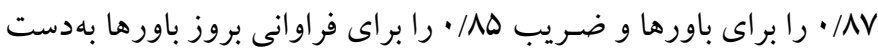

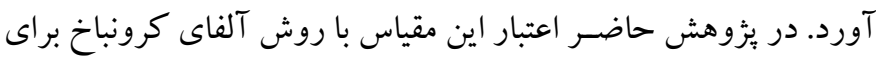

جدول ا: خلاصه جلسات درمانى يذيرش و تعهد

\begin{tabular}{|c|c|c|}
\hline محتواى جلسات & هدف & جلسات \\
\hline آشنايى، برقرارى رابطه درمانى و توضيح درباره اصول گروه، بحث در مورد ناتوانى فرزند و و مشكلات ناشى از آن براى مادران & آشنايى و معارفه & جلسه يكم \\
\hline ايجاد درماندگى خلاق، بيان استعاره خاه، انجام تمرين ذهن آكاهى، ارائه تكليف جلسه بعد & 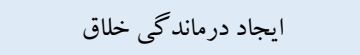 & 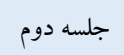 \\
\hline بازنخرى تكاليف جلسه قبل، معرفى مهار گرى به عنوان مشكل اصلى، استفاده از استعاره كيك شكلاتى، بيان مفهوم يذيرش، انجام & آشنايى با مفاهيم مهار گرى و يذيرش & جلسه سوم \\
\hline بازنخرى تكاليف جلسه قبل، بيان مفهوم گسلش و كاربرد تكنيكهاى مربوطه، انجام تمرين ذهن آكاهى، ارائه تكليف جلسه بعد & آشنايى با مفهوم گسلش شناختى & جلسه جهارم \\
\hline بازنخرى تكاليف جلسه قبل، آشنايى با مفهوم خود به عنوان زمينه، تضعيف خود مفهومى و بيان خود، ارائه تكليف جلسه بعد & آشنايى با مفهوم خود به عنوان زمينه & جلسه ينجم \\
\hline بازنخرى تكاليف جلسه قبل، گزارش ييشرفت درمان توسط بيماران و بيان تجربيات كسب شده در طى درمان، آشنايى با مفهوم & آشنايى با مفهوم ارزش ها & جلسه ششم \\
\hline بازنخرى تكاليف جلسه قبل با تاكيد بر يافتن ارزشها، معرفى مفهوم تعهد، ارائه تكليف جلسه بعد & آشنايى با مفهوم تعهد & جلسه هفتم \\
\hline بازنگرى تكاليف جلسه قبل با تاكيد بر مفهوم تعهد، بيان مفهوم عود، جمعبندى استفاده از اين برنامه، بايان درمان & بازنخرى و ارزيابى نهايى & جلسه هشتم \\
\hline
\end{tabular}

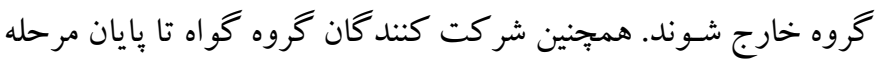

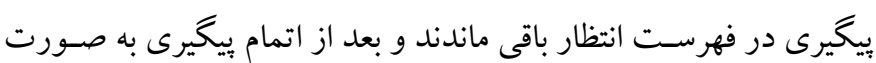

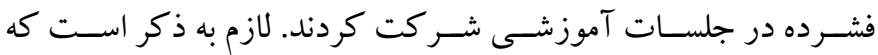
دادههاى به دست آمده با استفاده از روش هاى آمار توصيفى (ميانكين و

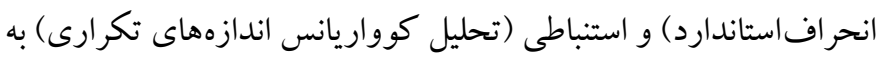
وسيله نرم افزار SPSS نسخه r ب تحليل شدند.

\section{يافتهها}

در جدول اشـاخص هاى توصيفى ابعاد درماندگى روانشناختى و افكار

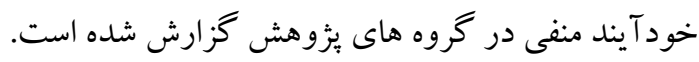

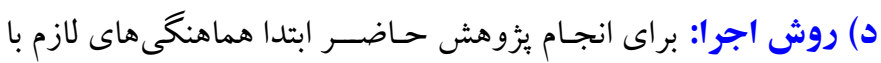

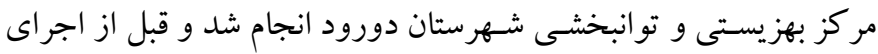

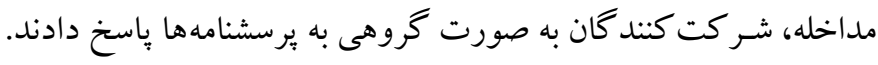

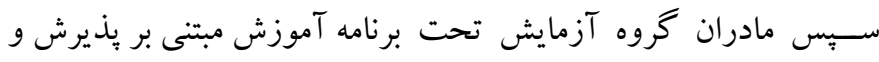

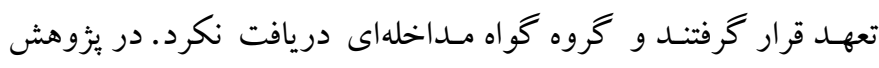
حاضر اصول اخلاقى به طور كامل رعايت شد، به طورى كه به افراد نمونه اطمينان داده شد كه اطلاعات حاصل از يرسشنامهها محرمانه باقى خو اهد ماند. شـركت كنند كان به صسورت كاملا تصادفى در دو گروه آزمايش و و

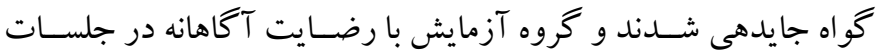
مداخله شـــركت كردند و آزادى عمل داشــتند كه هر موقع بخو اهند از 
جدول r: شاخصهاى توصيفى ابعاد درماندكى روانشناختى و افكار خودآيند منفى در كروه هاى يزوهش

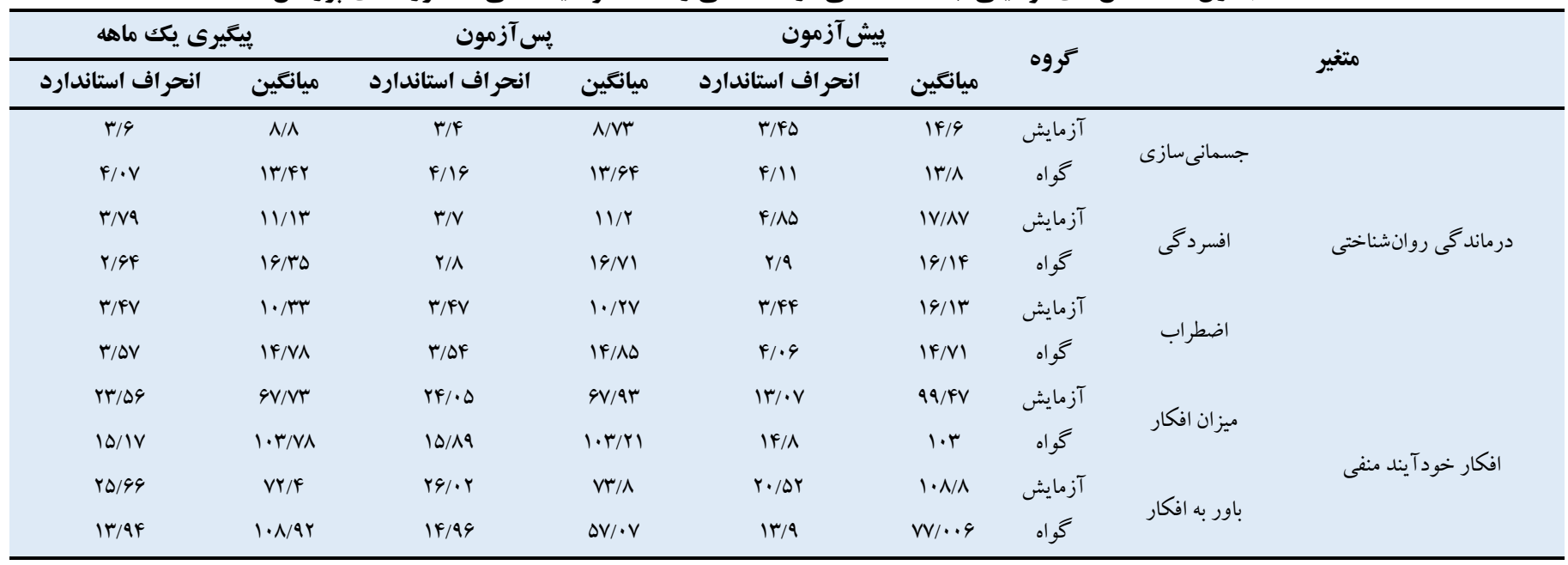

كوواريانس ها با كوواريانس كل از آزمون كرويت ماجلى استفاده است.

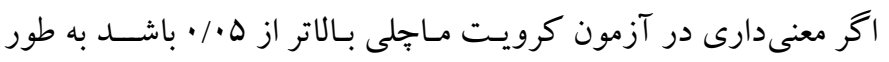

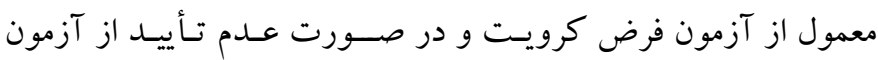

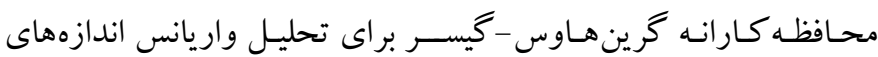

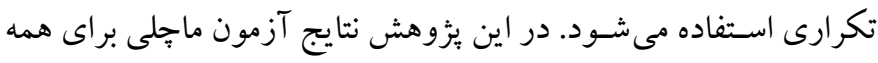

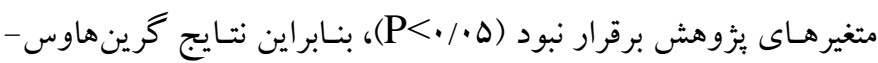

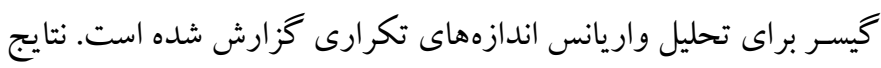

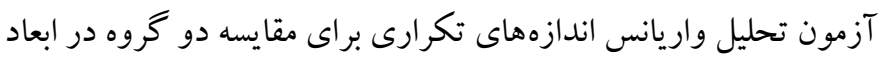

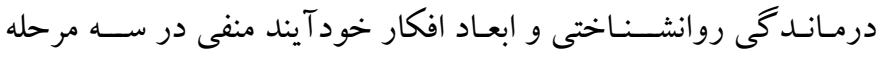

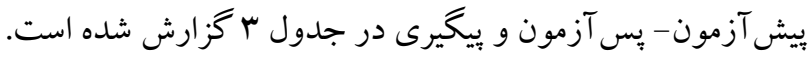

بر اسـاس نتـايج جـدول r، نمرات ميـانگين در همه ابعاد درماندگى روانشـناختى، يعنى جسمانى سازى، افسردگى، و اضطراب و ابعاد افكار

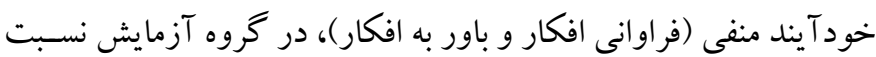

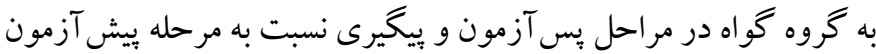
كاهش يافته است.

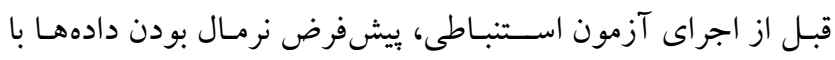

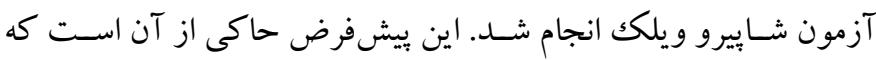

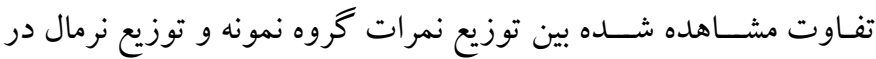

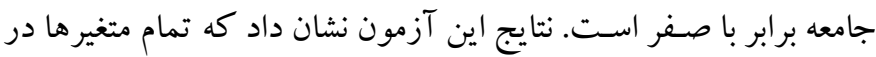

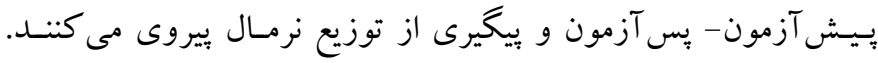

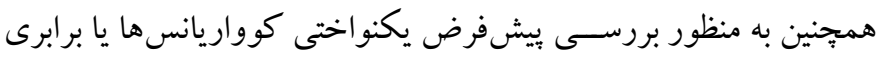

جدول "ّ: نتايج آزمون تحليل واريانس اندازههاى تكرارى جهت بررسى تفاوت كروهها در ابعاد درماندكى روانشناختى و افكار خودآيند منفى در سه مرحله بيش آزمون-

\begin{tabular}{|c|c|c|c|c|c|c|c|c|}
\hline توان آمارى & ميزان تأثير & Sig & $\mathbf{F}$ & ميانكين مجموع مجذورات & Df & مجموع مجذورات & منبع تغيير & مرحله \\
\hline $1 / \cdot$ & .1911 &.$\cdot \cdot 1$ & $+r / 99$ & $|r \cdot / \Lambda|$ & $1 / 01 f$ & INY/৭Dr & 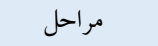 & \\
\hline$\cdot 109$ &.$/ 10$ & $\%$ r & $F / V M$ & ING/VYr & 1 & IAG/VYr & كرووها & جسمانىسازى \\
\hline $1 / \cdot$ & $\cdot / 090$ & $\cdot / \cdot 1$ & $r \Delta / \cdot q$ & $9 \mathrm{~V} / \cdot \mathrm{F}$ & $1 / 014$ & IFq/9०ץ & مراحل × گروه & \\
\hline $1 / \cdot$ & $\cdot / 9 \cdot r$ & $\% \cdot \cdot 1$ & $P Y / \cdot \Delta r$ & Irg/rr. & $1 / 4 \mid f$ & $19 r / 99 r$ & 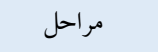 & \\
\hline $.194 \mathrm{~V}$ & $\cdot / 1 \vee 9$ & $\cdot / \cdot r r$ & $\Delta / A \vee \wedge$ & 199/1YA & 1 & 199/1rर & كروهها & افسردگى \\
\hline $1 / \cdot$ & $\cdot 190 \mathrm{~V}$ & $\% \cdot \cdot 1$ & $\Delta 1 / \Lambda \cdot V$ & IVI/ar. & $1 / F \mid F$ & TFY/IVD & مراحل × گروه & \\
\hline $1 / \cdot$ & . 1994 & $\cdot / \cdot 1$ & $4 \cdot / \mathrm{AVI}$ & Irg/IVr & $1 / r \Delta \Delta$ & ION/Tar & 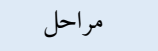 & \\
\hline$\cdot / F V \Delta$ & $\cdot /$ Tr &.$/ . \Delta 9$ & $r / A V$ & $1 F \cdot /$ Y99 & 1 & $14 \cdot / 199$ & كرووها & اضطراب \\
\hline $1 / \cdot$ & $\cdot / v \cdot 1$ & $\cdot / \cdot 1$ & $9 \Delta / \Delta r q$ & IrD/AFA & $1 / r \Delta \Delta$ & $|V \cdot / A T|$ & مراحل × گُروه & \\
\hline $1 / \cdot$ & $\cdot / \Delta 9 V$ & $\% \cdot \cdot 1$ & ra/rAr & FFAI/ITD & $1 / \cdot k F$ & $f q V a / \Lambda \cdot F$ & مراحل & ميزان افكار \\
\hline
\end{tabular}




\begin{tabular}{|c|c|c|c|c|c|c|c|c|}
\hline.$/ 991$ & $\cdot / r \Delta \varphi$ & $\cdot / \cdot \cdot 1$ & $1 F / q \cdot V$ & Irora/ror & 1 & Irarq/ror & كرووها & \\
\hline $1 / \cdot$ & $\cdot / \Delta \wedge r$ & $\cdot / \cdot 1$ & $r V / v \cdot \Delta$ & FVVD/IVq & $1 / . F F$ & Fq\G/MAF & مراحل × گرُوه & \\
\hline $1 / \cdot \cdot$ & .1991 & $\cdot / \cdot \cdot 1$ & GY/YA. & $\mathrm{VIFq/.9V}$ & $1 / I M F$ & $\Delta G M F / V D \Lambda$ & مراحل & \\
\hline - /AGF & $\cdot / T V Y$ & $\cdot / \cdot r$ & $1 . \% v r$ & מזגושזוו & 1 & מזואוזוI & كرووها & باور به افكار \\
\hline $1 / \cdot \cdot$ & . NTr & $\cdot / \cdot 1$ & $V F / Y \wedge \Delta$ & $\Delta Q Y Q / T T \Delta$ & $1 / 1 T F$ & $9 V r \cdot / 990$ & مراحل × گروه & \\
\hline
\end{tabular}

يُزوهش و عضويت گُوهى نيز در همه متغيرهاى بثزوهش معنى دار است

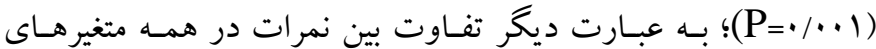
يُزوهش در ســه مرحله از ئزوهش در دو گروه معنى دار اسـتـ؛ بنابر اين

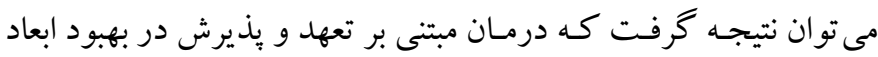

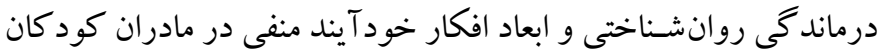

$$
\text { مبتلا به فلج مغزى مؤثر بو دهه است. }
$$

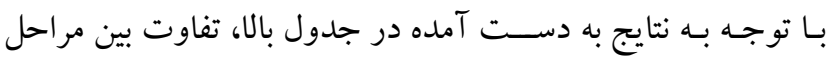

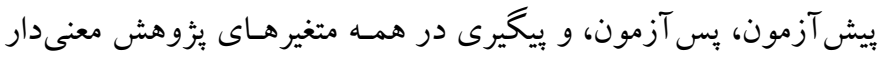

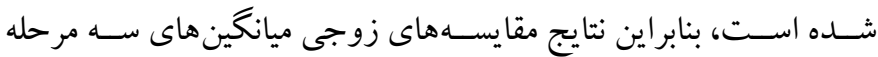

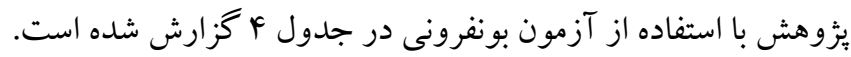

براســاس يـافته هاى به دســت آمده در جدول سا، تفاوت بين نمرات

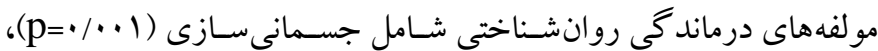

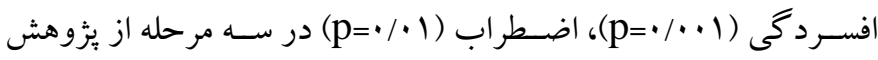

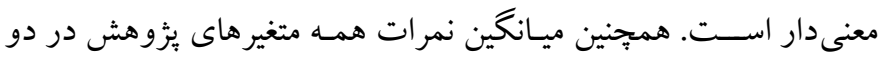

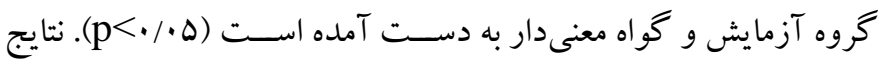

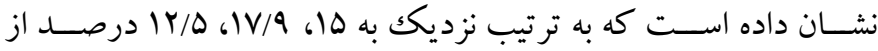
تفاوتهاى فردى در ابعاد درماندگى روانشناختى شامل جسمانى سازى، رده

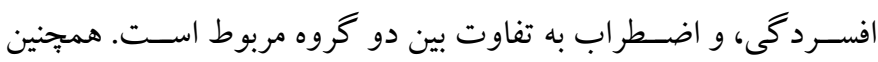

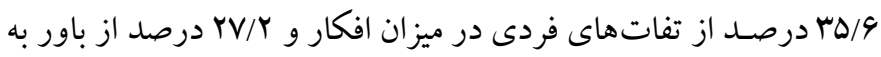

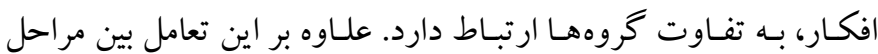

جدول ع: مقايسه زوجى ميانعين كروههاى درمان مبتنى بر يذيرش و تعهد و كواه در سه مرحله يزوهش در ابعاد درماندكى روانشناختى و افكار خودآيندمنفى

\begin{tabular}{|c|c|c|c|c|c|c|}
\hline \multicolumn{2}{|c|}{ فاصله اطمينان } & \multirow{2}{*}{ معنى دارى } & \multirow{2}{*}{ خطاى انحراف استاندارد } & \multirow{2}{*}{ تفاوت ميانكينها } & \multirow{2}{*}{ كروه ها } & \multirow{2}{*}{ متغيرها } \\
\hline حد بالا & حد يإين & & & & & \\
\hline$F /|r|$ & $1 / 90$ & $\% \cdot 1$ & . AKr & $r / \cdot F$ & يُش آزمون- يس آزمون & \\
\hline$F / r+1$ & 1/99V & $\cdot / \cdot 1$ & . & $r / l i f$ & ييش آزمون- ييخيرى & جسمانى سازى \\
\hline$\cdot / V 1 \Delta$ & $-\cdot / \Delta 9 V$ & $1 / \cdot$ & $\cdot /$ TOI & $\cdot / \cdot v^{k}$ & يس آزمون - يِيخيرى & \\
\hline$F / \cdot I V$ & $r / \cdot V \wedge$ &.$\cdots 1$ & $\cdot \pi$ & $r / .4 \Lambda$ & بيش آزمون- يس آزمون & \\
\hline$F / \Delta 91$ & $1 / 9 \Delta \wedge$ &.$\cdots 1$ &.$/ 01$ & r/Yq. & يِيش آزمون- يِيخيرى & | افسردگى \\
\hline.$/ 9 k T$ & $-\cdot / 019$ & $1 / \cdot$ & $\cdot /$ YA9 & $\cdot / r i r$ & يس آزمون - ييخيرى & \\
\hline r/AFr & $1 / M 1$ & $\% \cdot 1$ & $\cdot / M F \Lambda$ & r/AGY & يِي آزمون- بِ آزمون & \\
\hline r/ak9 & $r / \wedge r$ &.$/ \cdot 1$ & $\cdot / \pi \cdot 4$ & r/AGG & ي يِش آزمون- ييخيرى & اضطراب \\
\hline ./FYq & $-\cdot /$ FYF & $1 / \cdot$ &.$/ 19 V$ & $\% r$ & يس آزمون- يِيخيرى & \\
\hline KY/YYq & Q/·v. & $\% \cdot 1$ & $r / \Delta \wedge r$ & $10 / 99$ & يِش آزمون- يس آزمون & \\
\hline rY/IVF & $\Lambda / \wedge \cdot 1$ & $\% \cdot 1$ & $r / 9 / 4$ & $10 / F V F$ & يِيش آزمون- بيخيرى & ميز ان افكار \\
\hline.$/ 9 \Delta F$ & $-1 / T Y \Delta$ & $1 / \cdot$ &.$/ 4 F 4$ & $-\cdot / 1 \wedge 9$ & 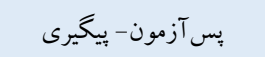 & \\
\hline$r Y / M V I$ & $11 / V V r$ &.$/ \cdot 1$ & $r / \cdot V q$ & $|V / \cdot v|$ & يِش آزمون سِ س آزمون & \\
\hline rY/9.r & $11 / \Delta \wedge r$ &.$/ \cdot 1$ & $r / 109$ & $\mathrm{IV} / \cdot 9 \mathrm{~T}$ & ييش آزمون- ييخيرى & باور به افكار \\
\hline $1 / 949$ & $-1 / \Delta 44$ & $1 / \cdot$ &.$/ 9 \pi r$ &.$/ r Y$ & بِ آزمون - يِيَيرى & \\
\hline
\end{tabular}

$(\mathrm{p}<\cdot / \cdot \Delta)$ 
همر اه با هوشـيارى كامل از شـرايط و موقعيت، و بودن لحظه به لحظه در

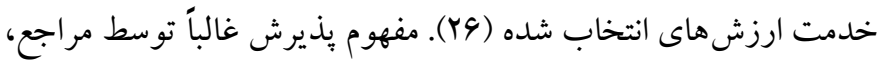

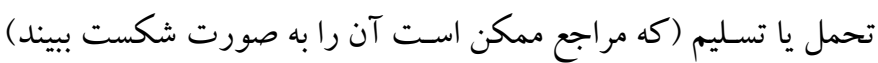
تعبير مىشود و استفاده از استعاره دو مقياس در اين درمان كمكك مى كند

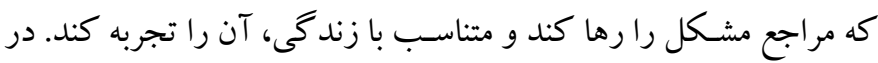

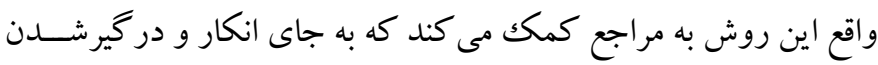

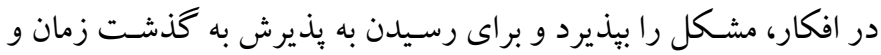

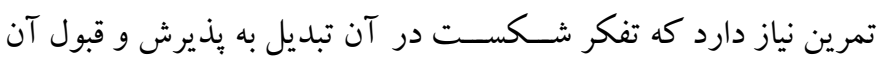

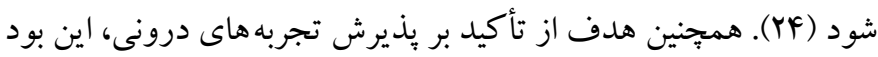
كه به شـر كت كنند كان در مداخله كمكك شــود تا افكار و احســاسـات آزاردهنده شان را فقط به عنوان يكك فكر تجربه كنند و از ناكار آمد بودن

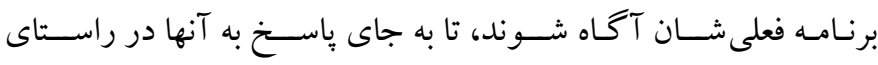
ارزشهايشـان حر كت كنند. همجنين در درمان مبتنى ير بذيرش و تعهد

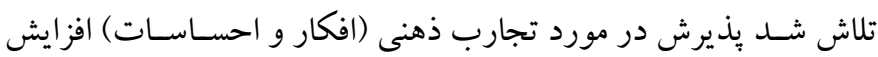

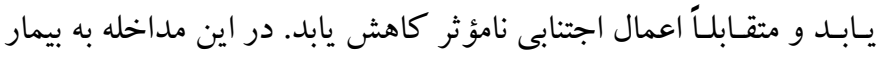

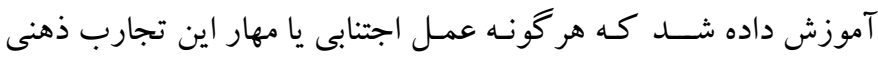

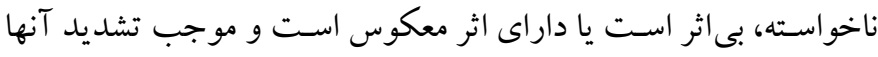

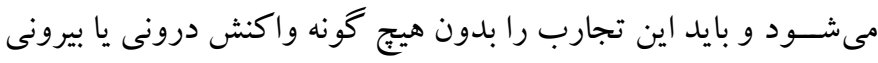

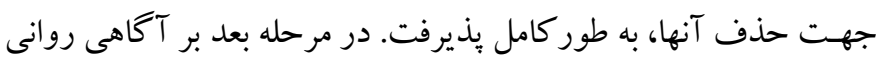

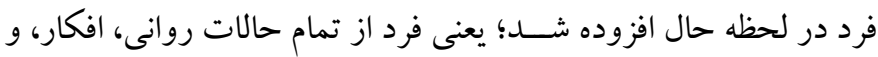

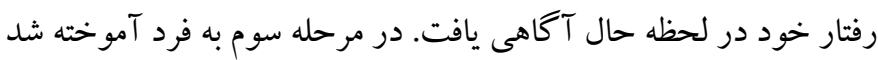
كه خود را از اين تجارب ذهنى جدا سازد (جداسازى شناختى)، به نحوى

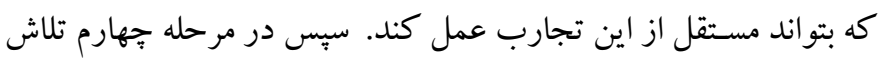
براى كاهش تمر كز مفرط بر خودتجسـمى يا داســان شـخصسى (مانند

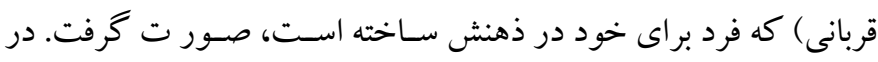

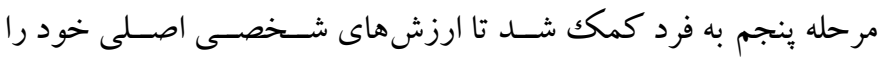

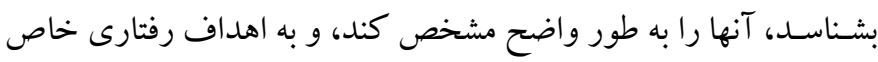

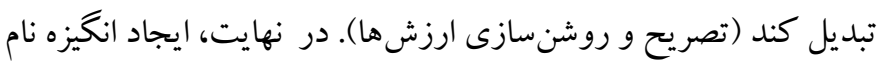

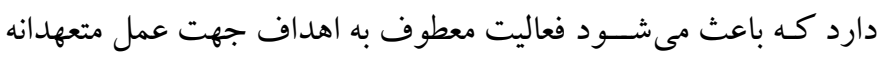

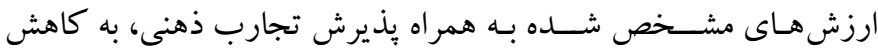

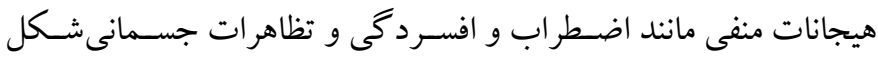

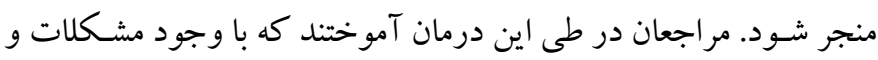

نتايج مقايسـههاى زوجى تفاوت ميانخين ها در سـه مرحله آزمون در

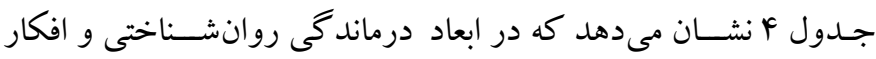

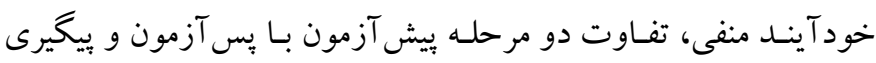

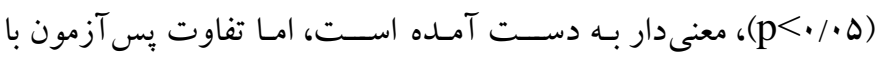

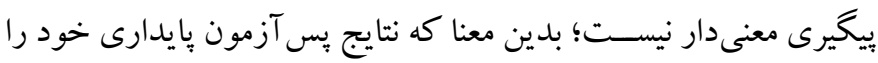
در مرحله بيخيرى حفظ كرده است.

\section{بحث و نتيجه تيرى}

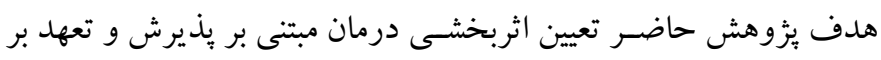

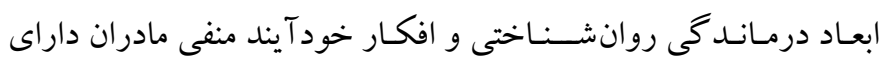

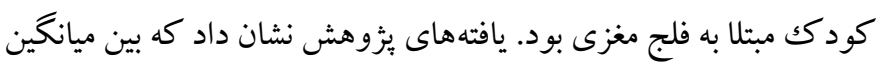

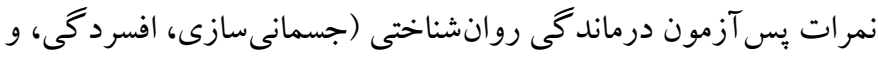

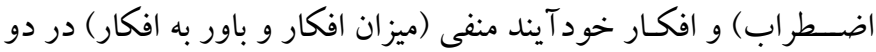

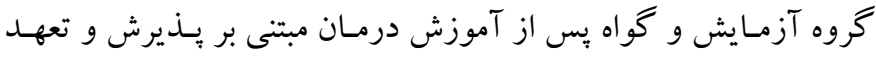

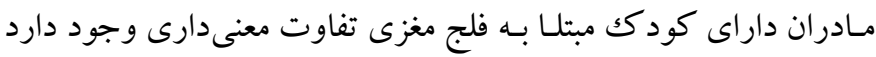

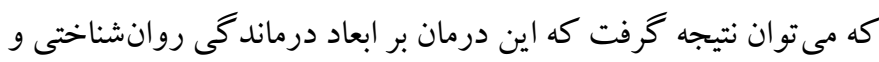

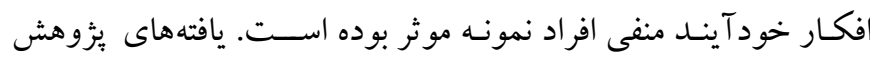

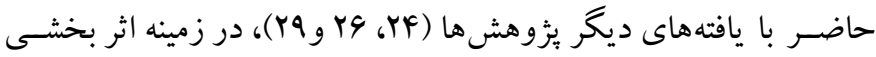
درمان مبتنى بر يذيرش و تعهد، همسو است. همجنين نتايج به دست آمده بـا يـافتههاى مطالعه حيدرى، ســاديان و حيدريان (YF) در زمينه تأثير

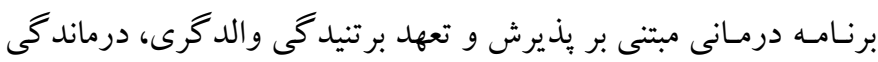

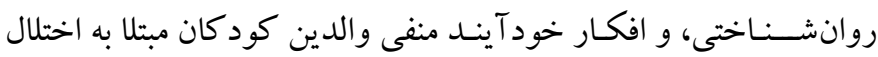

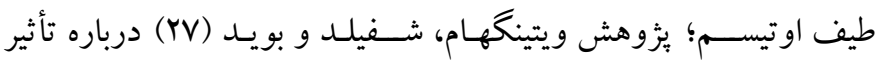

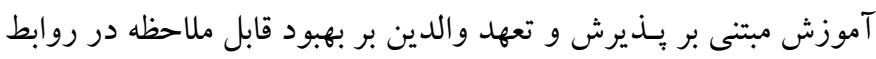

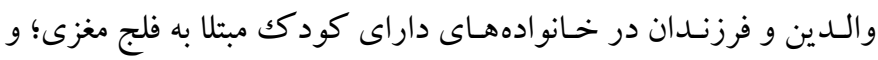

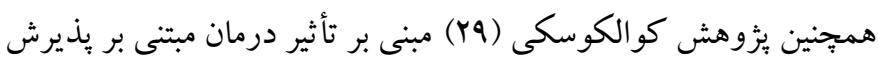

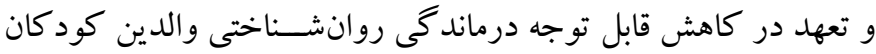

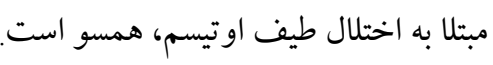

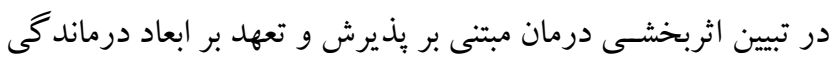

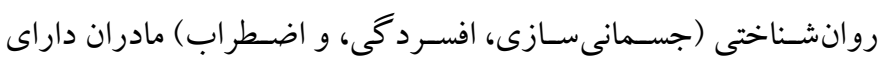

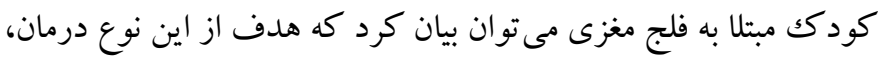
افزايش انعطـاف يـذيرى روانى اســت، يعنى توانـايى حفظ يا تغيير رفتار 
از محدوديتهاى اين بزوهش مىتوان به عدم استفاده كامل از روش

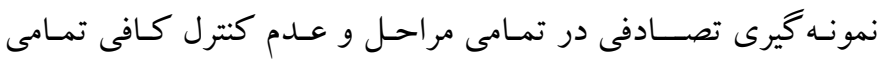

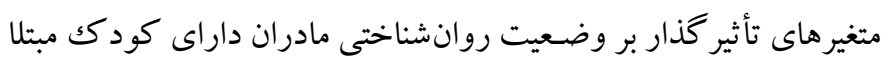

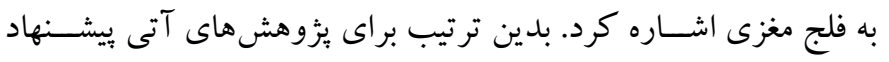

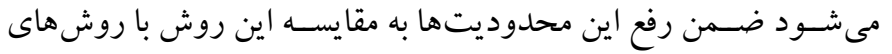

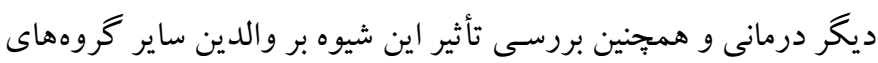

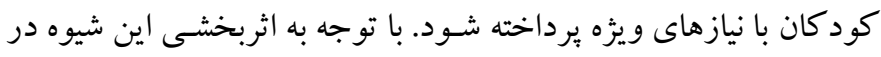

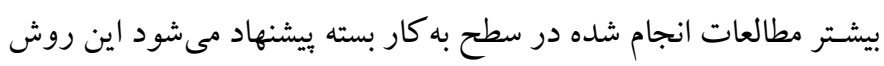
درمانى در مراكز مشـاوره و رواندرمانى (محيطهاى بالينى) براى مادران

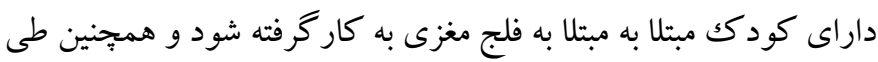
دورههـاى آموزشـى منظم و كـاربردى، اين شــــه به مشـــاوران مراكز آموزشى مانند مدارس، به طور كامل آموزش داده شود تا دانش آموزان

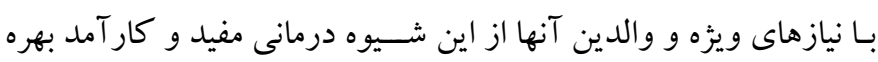

تشكر و قدردانى: اين بزوهش بركرفته از يايانامه كارشناسى ارشد در رشته

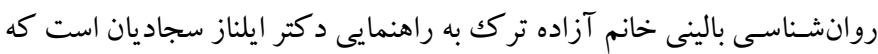

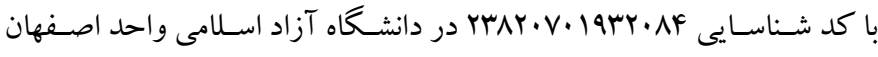
(خو راسـان) به تصويب رسيده است. همجنين مجوز اجراى آن بر روى افراد

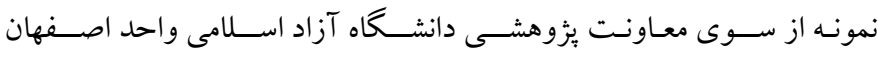

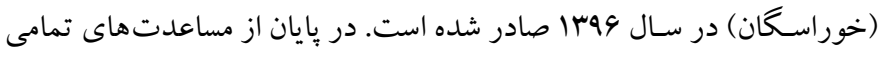

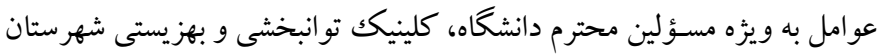

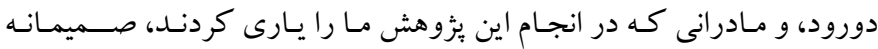

$$
\text { سباسگز ارى مىشود. }
$$

تضـاد منافع: اين يُزوهش براى نويسـند كان هيج گونه تضـاد منافع به دنبال

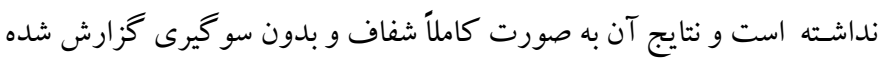

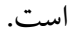

جو اب نـدادن به فكر، احســاس، علائم بدنى، خاطره، و ميل مى تواند از زندگى لذت ببرند و از خود رضايت داشته باشند و با وجود آنها در مسير

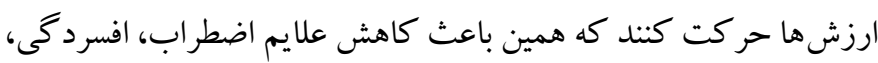

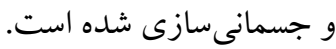
همجِين نتسايج اين مطـالعه نشــان داد كـه آموزش درمـان مبتنى بر

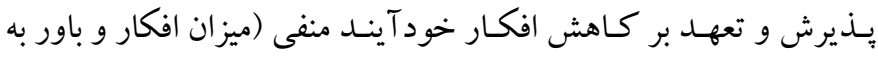
افكار ) مادران داراى كودك مبتلا به فلج مغزى اثربخش است. يافته هاى

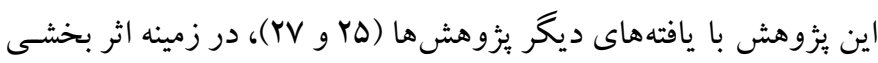

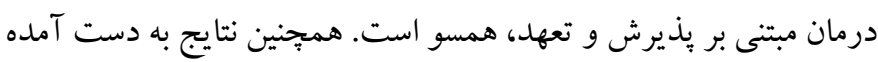

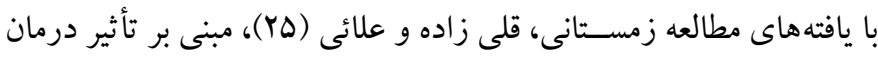
مبتنى بر يذيرش و تعهد در كاهش اضطر اب و افسـردگى مادران داراى

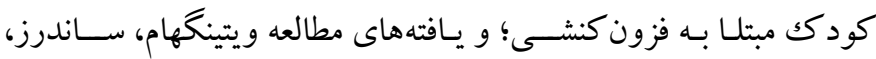

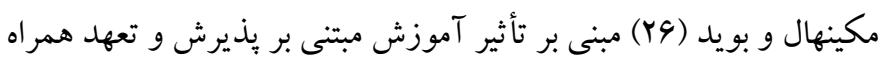

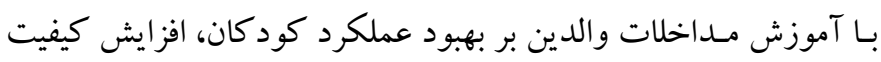
زنـدگى، و تنظيم روابط والـدين خانو ادههاى داراى كود كان مبتلا به فلج مغزى، در بافتى كلى تر همسو است.

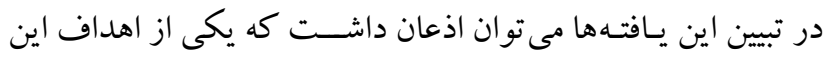

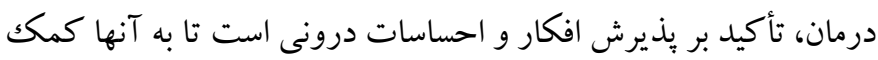

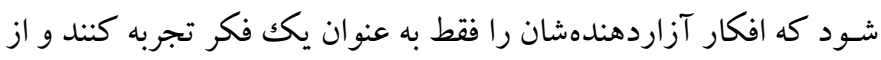

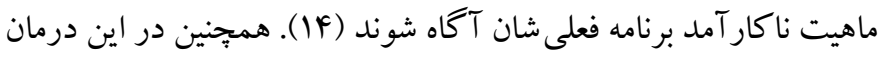

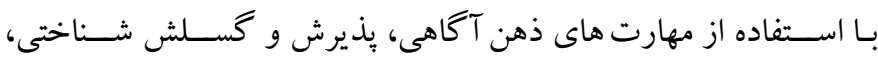
انعطاف يذيرى روانشـناختى افزايش مى يابد تابه جاى تمركز بر بر افكار و و

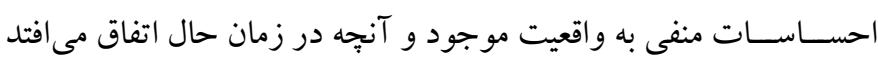

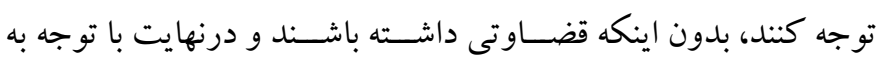
واقعيت موجود به شــيوهاى عمل كنند كه در مســير ارزشهايشــان قرار

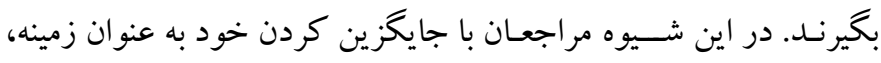

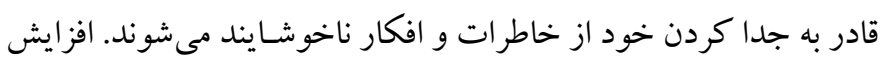
يذيرش در آنها باعث مى شود كه بلدون تمر كز بر افكار خود آيند منفى و و بدون قضاوت، متعهدانه به ارزش هايشان ببردازند. 


\section{References}

1. Jadidi M, Safary S, Jadidi M, Jamali S. Comparing social support and social anxiety between mothers of children with special needs and mothers of normal children. Knowledge \& Research in Applied Psychology. 2015; 16(2): 43-52. [Persian]. [Link]

2. Marrón EM, Redolar-Ripol D, Boixadós M, Nieto R, Guillamón N, Hernández E, et al. Burden on caregivers of children with cerebral palsy: predictors and related factors. Universitas Psychologica. 2013; 12(3): 767-777. [Link]

3. Jones KB, Wilson B, Weedon D, Bilder D. Care of adults with intellectual and developmental disabilities: cerebral palsy. FP Essent. 2015; 439: 26-30. [Link]

4. Hosseini SMS, Sourtiji H, Noorani Gharaborgha S, Hosseini SA. New rehabilitation approaches for upper limb function of children with hemiplegia. Archives of Rehabilitation. 2017; 18(3): 254-263. [Persian]. [Link]

5. Shanbhag DN, Krishanmurthy A. Mental health and quality of life of caregivers of individuals with cerebral palsy in a community based rehabilitation programme in rural karnataka. Disability, CBR \& Inclusive Development. 2011; 22(3): 29-38. [Link]

6. Case-Smith J, O'Brien JC. Occupational therapy for children. 6th ed. Maryland Heights, Mo.: Mosby/Elsevier; 2010, pp: 540-555. [Link]

7. Begum R, Desai O. A comparative study to evaluate psychological status of mothers of children with cerebral palsy and mothers of normal children. Indian journal of occupational therapy. 2010; 42(2): 3-9. [Link]

8. Sajedi F, Soleiman F, Ahmadi Ma. Cerebral palsy in children. Journal of Health and Care. 2013; 15(4): 8897. [Persian]. [Link]

9. Khamis V. Psychological distress among parents of children with mental retardation in the United Arab Emirates. Soc Sci Med. 2007; 64(4): 850-857. [Link]

10. Aghaei S, Yousefi Z. The effectiveness of quality of life therapy on psychological capitals and its dimensions among mothers of children with intellectual disability. Quarterly Journal of Child Mental Health. 2017; 4(2): 49-59. [Persian]. [Link]

11. Jalili N, Satari M, Rassafiani M. The impact of motor function of children with cerebral palsy on mothers' health status. Journal of Paramedical Sciences \& Rehabilitation. 2015; 4(4): 62-69. [Persian]. [Link]

12. Iversen AS, Graue M, Clare J. Parents' perspectives of surgery for a child who has cerebral palsy. J Pediatr Health Care. 2009; 23(3): 165-172. [Link]
13. Narimani M, Agha Mohammadian HR, Rajabi S. A comparison between the mental health of mothers of exceptional children and mothers of normal children. Journal of faundamental of mental health. 2007; 9(3334): 15-24. [Persian]. [Link]

14. Durá E, Andreu Y, Galdón MJ, Ferrando M, Murgui $\mathrm{S}$, Poveda R, et al. Psychological assessment of patients with temporomandibular disorders: confirmatory analysis of the dimensional structure of the Brief Symptoms Inventory 18. J Psychosom Res. 2006; 60(4): 365-370. [Link]

15. Snyder CR. Handbook of hope: theory, measures, and applications. San Diego, CA, US: Academic Press; 2000, pp: 402-415. [Link]

16. Rahbar Karbasdehi F, Abolghasemi A, Rahbar Karbasdehi E. Effect of stress management training based on cognitive-behavioral approach on improving parent- child relationship and psychological wellbeing in mothers of children with intellectual disability. Quarterly Journal of Child Mental Health. 2016; 3(3): 59-71. [Persian]. [Link]

17. Beck JS, Beck AT. Cognitive behavior therapy, second edition: basics and beyond. 2nd edition. New York: The Guilford Press; 2011, pp: 50-55. [Link]

18. BaBamiri M, Vatankhah M, Masumi Jahandizi H, Nemati M, Darvishi M. The relationship between coping styles, negative automatic thoughts, and hope with happiness in addicts of Ahvaz drug abuse rehabilitation clinics in 2011. J Adv Med Biomed Res. 2013; 21(84): 82-91. [Persian]. [Link]

19. Sheydayi Aghdam S, Shamseddini lory S, Abassi S, Yosefi S, Abdollahi S, Moradi joo $M$. The effectiveness of treatment based on acceptance and commitment in reducing distress and inefficient attitudes in patients with MS. Thoughts and Behavior in Clinical Psychology. 2015; 9(34): 57-66. [Persian]. [Link]

20. Movallali G, Pourmohamadreza Tajrishi M, Malayeri S. The effect of cognitive - behavioral therapy on general health and depression symptoms in mothers of deaf children. Exceptional Education Journal. 2014; 9(122): 6-16. [Persian]. [Link]

21. Hayes SC, Luoma JB, Bond FW, Masuda A, Lillis J. Acceptance and commitment therapy: model, processes and outcomes. Behav Res Ther. 2006; 44(1): 1-25. [Link]

22. Bach P, Moran DJ. ACT in practice: conceptualization of acceptance and commitment therapy. Sara Kamali \& Niloofar Kian Rad (Persian Translator). Tehran: Arjmand Press; 2015, p: 34. [Persian]. 
23. Izadi R, Abedi M. Acceptance and commitment therapy. 3th Edition. Tehran: Jungel Publish; 2014, p: 160. [Persian].

24. Heidari S, Sajjadian I, Heidarian A. The effectiveness of acceptance and commitment group therapy on psychological distress and negative automatic thoughts in mothers of children with autism spectrum disorder. Journal of Fundamentals of Mental Health. 2016; 18(Special Issue): 491-499. [Persian]. [Link]

25. Zemestani M, Gholizadeh Z, Alaei M. Effectiveness of acceptance and commitment therapy on depression and anxiety of ADHD childrens' mothers. Psychology of Exceptional Individuals. 2018; 8(29): 61-84. [Persian]. [Link]

26. Whittingham K, Sanders MR, McKinlay L, Boyd RN. Parenting intervention combined with acceptance and commitment therapy: a trial with families of children with cerebral palsy. J Pediatr Psychol. 2016; 41(5): 531-542. [Link]

27. Whittingham K, Sheffield J, Boyd RN. Parenting acceptance and commitment therapy: a randomised controlled trial of an innovative online course for families of children with cerebral palsy. BMJ Open. 2016; 6(10). e012807. [Link]

28. Montgomery D. The effects of acceptance and commitment therapy on parents of children diagnosed with autism [Ph.D. Thesis]. [Minnesota, United States]: Department of Psychology, Walden University; 2015, pp: 85-86. [Link]

29. Kowalkowski J. The impact of a group-based acceptance and commitment therapy intervention on parents of children diagnosed with an autism spectrum disorder [Ph.D. Thesis]. [Michigan, United States]: Department of Psychology, Eastern Michigan University; 2012, pp: 6-25. [Link]

30. Krigger KW. Cerebral palsy: an overview. Am Fam Physician. 2006; 73(1): 91-100. [Link]
31. Derogatis LR, Fitzpatrick M. The SCL-90-R, the Brief Symptom Inventory (BSI), and the BSI-18. In: Maruish ME, editor. The use of psychological testing for treatment planning and outcomes assessment: Instruments for adults. Mahwah, NJ, US: Lawrence Erlbaum Associates Publishers; 2004, pp: 1-41. [Link]

32. Galdón MJ, Durá E, Andreu Y, Ferrando M, Murgui $\mathrm{S}$, Pérez $\mathrm{S}$, et al. Psychometric properties of the Brief Symptom Inventory-18 in a Spanish breast cancer sample. J Psychosom Res. 2008; 65(6): 533-539. [Link]

33. Recklitis CJ, Parsons SK, Shih M-C, Mertens A, Robison LL, and Zeltzer L. Factor structure of the brief symptom inventory--18 in adult survivors of childhood cancer: results from the childhood cancer survivor study. Psychol Assess. 2006; 18(1): 22-32. [Link]

34. Andjreu Y, Galdón MJ, Dura E, Ferrando M, Murgui $\mathrm{S}$, García A, et al. Psychometric properties of the brief symptoms inventory-18 (BSI-18) in a Spanish sample of outpatients with psychiatric disorders. Psicothema. 2008; 20(4): 844-850. [Link]

35. Hollon SD, Kendall PC. Cognitive self-statements in depression: Development of an automatic thoughts questionnaire. Cognit Ther Res. 1980; 4(4): 383-395. [Link]

36. Kazemi AS, Banijamali SA, Ahadi H, Farrokhi N. Evaluation of effectiveness of training cognitive behavioral strategies in the secondary traumatic stress disorder (STSD) symptoms and psychological problems among devotees' wives with chronic PTSD due to war. Medical Science Journal of Islamic Azad Univesity - Tehran Medical Branch. 2012; 22(2): 122129. [Persian]. [Link] 